\title{
Evaporation in a Mediterranean environment by energy budget and Penman methods, Lake Baratz, Sardinia, Italy
}

\author{
F. Giadrossich ${ }^{1}$, M. Niedda ${ }^{1}$, D. Cohen ${ }^{2}$, and M. Pirastru ${ }^{1}$ \\ ${ }^{1}$ Dipartimento di Agraria, University of Sassari, via Enrico de Nicola 1, 07100 Sassari, Italy \\ ${ }^{2}$ Department of Geological and Atmospheric Sciences, Iowa State University, Ames, IA 50011, USA
}

Correspondence to: F. Giadrossich (fgiadrossich@uniss.it)

Received: 21 November 2014 - Published in Hydrol. Earth Syst. Sci. Discuss.: 10 February 2015

Revised: 23 April 2015 - Accepted: 1 May 2015 - Published: 22 May 2015

\begin{abstract}
In Mediterranean environments, evaporation is a key component of lake water budgets. This applies to Lake Baratz in Sardinia, Italy, a closed lake that almost dried up in 2008 after a succession of years with low seasonal rainfall. We used the energy budget method and Penman's equation to estimate evaporation over Lake Baratz. We measured, using a raft station, water temperature at the surface, at 1,2, 4, $6 \mathrm{~m}$ depth and at the bottom of the lake, as well as air temperature, relative humidity, wind speed, and net radiation over a period of 3 years. We also compared Penman's equation and the energy budget method in two other climatic zones using published data. Our results indicate that mean yearly evaporation over Lake Baratz was $950 \mathrm{~mm}$. On an annual scale, evaporation estimated by Penman's method omitting heat storage as is usually done was $18 \%$ higher than by the energy budget method that included heat storage, with monthly differences ranging between -38 and $+60 \%$. Including the heat storage term in Penman's equation changed the monthly values but did not change the yearly value significantly. Solar radiation and heat storage were found to be the most important energy fluxes to and from the lake and had the greatest effect on evaporation rates for the energy budget method. The bias between the two methods has a seasonal cycle due to the storage and release of energy from the lake. Energy advected to and from the lake by precipitation, surface water and ground water had minor effect on evaporation rates. Lake Baratz, like other lakes in a Mediterranean environment, is particularly sensitive to the summer hot and dry climate. In contrast, we found that rates of evaporation estimated from Penman and the energy budget methods over tropical African lakes were nearly constant over the entire year and the difference between the two methods smaller. Difference between
\end{abstract}

the two methods for North American lakes is also smaller probably owing to the ice-cover season and to lower radiation and lower temperatures during summer.

\section{Introduction}

Lakes in semi-arid regions like around the Mediterranean Sea are extremely sensitive to changes in climate and land use. In the summer, low precipitations, high temperatures and insolation contribute to high rates of evaporation. Recent increases in drought frequency (Hoerling et al., 2012), often exacerbated by excessive water extraction either directly from lakes or from aquifers beneath, have caused lake levels in the region to decrease significantly (Myronidis et al., 2012; Gianniou and Antonopoulos, 2007). This has tremendous negative impacts on water quality and eutrophication problems (Sechi and Luglié, 1996; Gianniou and Antonopoulos, 2007), local and regional ecosystem, and the economy (O'Reilly et al., 2003; Gianniou and Antonopoulos, 2007; Pham et al., 2008).

The water level in a lake reflects the balance between water inputs (precipitation, runoff, groundwater) and water losses (evaporation, outlet streams, groundwater) making it a sensitive indicator of climate change (Adrian et al., 2009; Williamson et al., 2009). Lake Baratz in Sardinia, Italy (Fig. 1), suffered significant changes in its water level over the last 10 years and almost dried up in 2008 because of a succession of years with low seasonal rainfall (Fig. 2). This decrease in precipitation together with water losses by evaporation and infiltration were not balanced by other water influx. Historically, precipitation in the region is highly vari- 

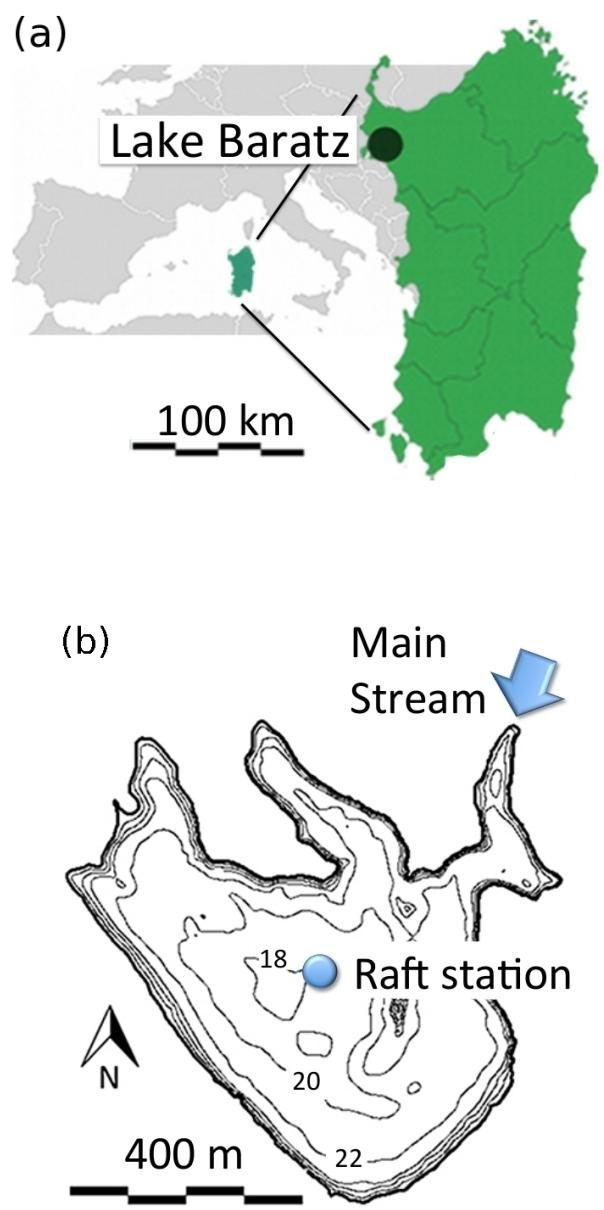

Figure 1. (a) Location of Lake Baratz, Sardegna, Italy. (b) Bathymetric map. Numbers are $\mathrm{m}$ a.s.l. Contours are every $2 \mathrm{~m}$ from 18 to 28 m a.s.l.

able with dry years alternating with wet ones as, for example, during the 1970-2010 period. The effects of the dry period were exacerbated by land use changes in the catchment area over the last 50 years (Niedda et al., 2014). After nearly drying up in 2008 (lake depth $<3 \mathrm{~m}$, Fig. 2), the water level increased over $7 \mathrm{~m}$ between 2008 and 2011 due to rainfall $30 \%$ in excess of the annual average $\left(590 \mathrm{~mm} \mathrm{a}^{-1}\right.$ based on the period 1970 to 2010). Although droughts and climate change are not the only causes of the low water level, this extremely low water level observed in 2008 is rare with a recurrence time estimated at 100 years (Niedda et al., 2014). In this context, estimating evaporation can help to understand drought phenomena and the effects of climate and land-use changes on the lake water balance.

One of the most accurate methods for estimating long-term lake evaporation is the energy budget method expressed as the Bowen Ratio Energy Budget (BREB) (Harbeck et al., 1958; Lenters et al., 2005; Rosenberry et al., 2007). The application of this method requires measurements of the heat storage of the lake through the collection of the wa-

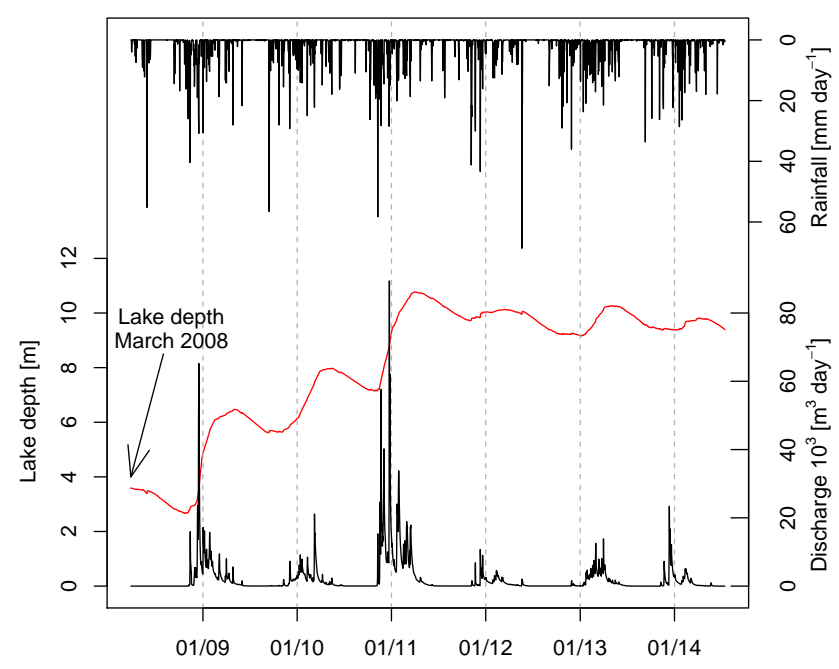

Figure 2. Time series of daily precipitation, lake depth (measured at centre of lake), and modelled stream discharge into the lake (Niedda and Pirastru, 2012)) from April 2008 to April 2014.

ter temperature at different depths. Obtaining lake temperature and meteorological variables directly at the lake surface using a raft station is not common because of its high cost. Studies on lake evaporation that estimate heat storage from measurements made from raft stations are few but are available from Williams Lake, Minnesota (Sturrock et al., 1992), Lake Serra Azul, Brazil (dos Reis and Dias, 1998), Mirror Lake, New Hampshire (Winter et al., 2003), Lake Valkea-Kotinen, Finland (Nordbo et al., 2011), Nasser Lake, Egypt (Elsawwaf et al., 2010), Lake Lucerne, Florida (Lee et al., 1991), Wetland P1 in the Cottonwood Lake area, North Dakota (Parkhurst et al., 1998), and Lake Taihu, China (Wang et al., 2014).

A simpler method for estimating evaporation is the Penman equation. It combines the heat and mass transfer balance equations for a wet surface and requires meteorological parameters relatively simple to obtain such as net radiation, air temperature, humidity and wind speed. In theory, Penman's equation requires knowledge of the net available energy, i.e. the net radiation minus the heat storage (see for example Brutsaert, 1982; Shuttleworth, 1993). In practice, however, and in Penman's (1948) original work, the heat storage term is entirely omitted because of the difficulty of obtaining such data. Neglecting that term limits the accuracy of the Penman model because it does not take into consideration the dynamics linked to the warming and cooling of the water mass. Although Penman's equation, or other related methods (e.g. the Priestley-Taylor equation, Priestley and Taylor, 1972), is often sufficient to estimate water balance of artificial or natural basins, the application of the energy budget is essential for a correct calibration of these simpler models that use limited meteorological observations (Rosenberry et al., 2007). In this study we include the heat storage term in 
BREB but exclude it from the Penman equation because this is the most common situation for practitioners and also the most reported case in the literature. It is one of our objectives to estimate the bias introduced by neglecting the heat storage term in Penman's model for cases when lake water temperature is unavailable. BREB, using all terms of the heat budget, thus represents a reference model for estimation of evaporation.

Despite many energy budget studies, comparisons between BREB and Penman's methods are few (e.g. Winter et al., 1995; Yin and Nicholson, 1998; Vallet-Coulomb et al., 2001; Shanahan et al., 2007; Rosenberry et al., 2007). In those papers, the two methods yield a difference ranging between 5 and $20 \%$. Studies are concentrated in tropical Africa, and in north-central and northeastern America. These studies have never been compared in terms of their climatic zones. A humid continental climate (e.g. Robertson and Barry, 1985; Sturrock et al., 1992; Winter et al., 2003) as found in North America is characterized by short, cool summers and long, cold winters, while a tropical climate is characterized by almost constant temperature and summer monsoon. In contrast, in a Mediterranean semi-arid climate, rainfall occurs outside the hot season when most of evaporation takes place. Also, total precipitation is significantly less and there is no snow melt.

In the present study, components of the energy budget are measured using a raft station to estimate the long-term seasonal evaporation of a Mediterranean lake. Our objectives are to: (i) assess the amount of evaporation from Lake Baratz, (ii) compare BREB and Penman's model to evaluate such evaporation losses at seasonal timescales, and (iii) compare the evaporation estimates by Penman and BREB with evaporation from other climatic zones.

\section{Materials and methods}

\subsection{Study site}

Lake Baratz is a closed lake located $1 \mathrm{~km}$ from the Mediterranean Sea in the northwestern part of the island of Sardinia, Italy $\left(40^{\circ} 40^{\prime} 52.15^{\prime \prime} \mathrm{N} 8^{\circ} 13^{\prime} 32.89^{\prime \prime} \mathrm{E}\right)$ (Fig. 1). Today, the lake is about $27 \mathrm{~m}$ a.s.l., its surface area is $0.45 \times 10^{6} \mathrm{~m}^{2}$ and its volume about $2 \times 10^{6} \mathrm{~m}^{3}$. Mean depth is $4 \mathrm{~m}$ and maximum depth is $9 \mathrm{~m}$. The lake waters are eutrophic and brackish because of ionic contents due to evaporitic formations and elevated amounts of nitrogen and phosphates from pastures, crops and other human activities. As a result, the density of phytoplankton such as Chlamidomonas, Prymnesium, Anabaena, Microcystis, and Aphanizomenon is high (Sechi and Luglié, 1996).

The catchment drainage area is about $12 \mathrm{~km}^{2}$. Only one significant creek with a tributary flows into the lake. The maximum catchment elevation is $410 \mathrm{~m}$ a.s.l., with mean elevation $122 \mathrm{~m}$ and mean slope $12.4 \%$. The climate is Mediter- ranean, semi-arid, with seasonal high water deficit during summers and cold-wet winters separated by two seasons of intermediate character. Mean annual temperature and relative humidity are $15.8^{\circ} \mathrm{C}$ and $78.7 \%$, respectively, and minimum and maximum mean daily temperatures are 3 and $29^{\circ} \mathrm{C}$, respectively. Average annual precipitation is $590 \mathrm{~mm}$, with about $76 \%$ of this concentrated between November and March (see Fig. 2). There is no precipitation in summer. Autumn precipitation causes no stream discharge into the lake owing to dry conditions. Water inflow starts usually in December and ends in May. During the dry season the lake water balance is governed by open water evaporation and the lake level decreases by about 0.8 to $1 \mathrm{~m}$. Average annual lake evaporation is approximately $1000 \mathrm{~mm}$, with about $72 \%$ of this concentrated between April and September. The bottom of the lake sits on Permian sandstone and all of the southern part of the lake basin is considered impermeable although the study of Niedda and Pirastru (2012) shows that the lake bed has groundwater exchange of the same order of magnitude as evaporation but precise estimates remain difficult. Lake Baratz is a rarity as it is the only natural lake in Sardinia. It was declared a Site of Community Importance (SCI) as defined by the European Commission Habitats Directive (92/43/EEC), a site which contributes significantly to the maintenance of biological diversity. Moreover, the catchment has been an experimental site for the study of hydrological balance at catchment scale in a Mediterranean environment (Niedda et al., 2014).

\section{Field data collection}

Air temperature, relative humidity, wind velocity and net radiation were measured from both a land and a raft station $2 \mathrm{~m}$ above the land or water surface. The land station, located about $2 \mathrm{~km}$ northeast of the lake, has been collecting data since April 2008, while the raft station, anchored in the middle of the lake, has been in operation since April 2011. Atmospheric pressure and rainfall were measured from the land station only. The raft station was equipped with a Campbell Scientific anemometer (model 05103, accuracy $\pm 0.3 \mathrm{~m} \mathrm{~s}^{-1}$ ), a Campbell Scientific temperature and relative humidity probe $(\mathrm{CS} 215$, accuracy $\pm 0.4 \mathrm{~K}$ and $\pm 2 \%$ over $10-$ $90 \%$ relative humidity at $25^{\circ} \mathrm{C}$ ), and a Campbell Scientific NR-Lite net radiometer (spectral range 0.2 to $100 \mu \mathrm{m}$ ).

Lake water temperature was measured with either a Schlumberger's Mini-Diver DI501 or a Mini-Diver DI502 (accuracy $\pm 0.2 \mathrm{~K}$, pressure accuracy $0.25 \%$ ) for the lake bottom temperature and Campbell Scientific 107-L temperature probes (accuracy $\pm 0.2 \mathrm{~K}$ ) anchored below the raft for temperatures at the lake surface and at depths of 1, 2, 4, and $6 \mathrm{~m}$ below the surface (see Fig. A1 in Appendix A). In the first year (July 2011 to August 2012), temperature profiles were manually collected during site surveys every 2 to 5 weeks at six locations on the lake surface. In the second and third years (August 2012 to July 2014) data were collected automatically 
and recorded continuously every hour from only one raft station at the centre of the lake. This decision was supported by the data of the first year of survey that showed negligible difference in water temperature between different survey points (Crow and Hottman, 1973). Lake-level change was estimated from the pressure change measured by the Mini-Diver (correcting for changes in atmospheric pressure measured at the land station) and also from the water level in a borehole near the lake using a phreatimeter.

Water discharge and water temperature of the creek were measured by a current metre and a thermistor, respectively, installed on the stable bed of a trapezoidal concrete channel upstream of the tributary. A triangular weir was installed immediately downstream from the current metre to measure low flows, which the current metre does not do well.

Prior to February 2014 climatic data were logged every 5 min with hourly averages computed and stored. Thereafter, data were sampled every $10 \mathrm{~min}$ and averages recorded every hour. Logging was done by a Campbell Scientific CR1000 powered by a photovoltaic panel. On 24 September 2013 the raft sank and was only reassembled the next spring on 25 April 2014. The diver measuring the bottom temperature and the lake level kept working during that time. Surface temperature was measured again starting on 4 March 2014. When the raft was not in operation, missing meteorological data were filled with data from the land station using linearly regression (smallest values of the correlation coefficients are 0.72 for wind and 0.82 for relative humidity; for temperature, maximum temperature, net radiation, the correlation coefficients are higher than 0.93). Also the lake temperature at all depths was assumed to equal the bottom temperature based on temperature records from prior years (see Sect. 3.3).

Regarding the survey data, the variables required to use Penman's formula are net radiation, water surface and air temperatures, wind speed and relative humidity. The change in heat storage in the water body is the main cost of data acquisition and is needed to apply BREB. In our case, our fully equipped raft station (including temperature profile) was less than EUR 6000 in 2011.

\subsection{The BREB method}

The energy balance for a water body neglecting heat exchanges from groundwater is (e.g. Brutsaert, 1982)

$R_{\text {net }}+A_{\text {net }}-E_{\mathrm{B}}-H=\Delta S$,

where $R_{\text {net }}$ is the net radiative flux density, $A_{\text {net }}$ the net heat advected into the lake expressed as a specific flux, $E_{\mathrm{B}}$ the latent heat flux, $H$ the sensible heat flux, and $\Delta S$ the change of energy storage per unit area due to temperature and volumetric changes over a time period $\Delta t$. All energy fluxes in Eq. (1) are in units of $\mathrm{W} \mathrm{m}^{-2}$. The net heat advected into the lake is
$A_{\text {net }}=A_{\mathrm{i}}+A_{\mathrm{p}}-A_{\mathrm{e}}=\rho_{\mathrm{w}} c_{\mathrm{w}}\left(F_{\mathrm{i}} T_{\mathrm{i}}+F_{\mathrm{p}} T_{\mathrm{p}}\right)-\frac{c_{\mathrm{w}} E_{\mathrm{B}} T_{\mathrm{s}}}{\lambda}$,

where $A_{\mathrm{i}}$ is heat advected into the lake by stream inflow, $A_{\mathrm{p}}$ by precipitation, and $A_{\mathrm{e}}$ is heat loss due to water evaporation; $\rho_{\mathrm{w}}$ is the density of water $\left(1000 \mathrm{~kg} \mathrm{~m}^{-3}\right), c_{\mathrm{w}}$ is the specific heat of water $\left(4186 \mathrm{~J} \mathrm{~kg}^{-1} \mathrm{~K}^{-1}\right), F_{\mathrm{i}}$ and $F_{\mathrm{p}}$ are the influxes of water from the stream and precipitation, $T_{\mathrm{i}}$ and $T_{\mathrm{p}}$ are the stream and precipitation temperature, and $T_{\mathrm{s}}$ is the lake water surface temperature. The latent heat of vaporization of water, $\lambda$, is calculated as a function of the surface temperature of water as (Shuttleworth, 1993)

$\lambda=10^{6}\left(2.501-0.002361 T_{\mathrm{s}}\right) \quad\left(\mathrm{J} \mathrm{kg}^{-1}\right)$.

To estimate stream discharge into the lake we use the finite difference distributed model of coupled subsurface-channel flow developed for Lake Baratz catchment of Niedda and Pirastru (2012). This calibrated model uses the measured stream discharge of the creek to estimate discharge into the lake for the whole basin.

The heat storage term, $\Delta S$, at time $t$ is estimated as

$\Delta S(t)=\frac{\rho_{\mathrm{w}} c_{\mathrm{w}}}{A(t) \Delta t} \sum_{i=1}^{n_{i}} V_{i} \Delta T_{i}$,

where $A(t)$ is the lake surface area (a function of lake surface elevation and thus time), $n_{i}$ is the number of layers (six) where temperature is measured, $\Delta T_{i}=T_{i}(t)-T_{i}(t-\Delta t)$ is the temperature difference of layer $i$ over the time step $\Delta t$, $V_{i}=V\left(z_{i}\right)-V\left(z_{i}-h_{i}\right)$ is the volume of layer $i, z_{i}$ is the height from the bottom of the lake to the top of layer $i$ (see Appendix A), $h_{i}$ is the thickness of layer $i$, and $V($.$) is the$ lake volume averaged over the time step. Variations of lake level are included in the calculation. Lake volume $V$ and lake surface area $A$ are estimated from polynomials as a function of water height (measured from bottom) whose coefficients have been obtained using the $1 \mathrm{~m}$ resolution bathymetric map of 1995 (Fig. 1b). Values of coefficients are optimized by limiting the depth to $12 \mathrm{~m}$ for the volume and by considering only lake level in the range of 8 to $12 \mathrm{~m}$ (measured from bottom) to estimate the surface area. These polynomials are

$V(z)=23.311 z^{5}-850.67 z^{4}+8389.9 z^{3}-2223.1 z^{2}+3635.8 z$,

and

$A(z)=6.306 z^{6}-305.94 z^{5}+5926.8 z^{4}-57052 z^{3}+269589 z^{2}-444278 z$,

where $z$ is measured from the deepest point in the lake.

In Eqs. (1) and (2), all terms except $E_{\mathrm{B}}, H$, and $A_{\mathrm{e}}$ can be obtained directly from measurements. The sum of the known terms $\left(R_{\text {net }}+\Delta S\right)$ is the available energy. Writing the sensible heat as a function of the latent heat using the Bowen ratio (Bowen, 1926) $(\beta=H / E)$ in Eq. (1), combining Eq. (1) 
with Eq. (2) and solving for $E_{\mathrm{B}}$, we obtain (Anderson , 1954; Webb, 1964; Lenters et al., 2005; Rosenberry et al., 2007)

$$
E_{\mathrm{B}}=\frac{\bar{R}_{\text {net }}-\overline{\Delta S}+\rho_{\mathrm{w}} c_{\mathrm{w}}\left(\bar{F}_{\mathrm{i}} \bar{T}_{\mathrm{i}}+\bar{F}_{\mathrm{p}} \bar{T}_{\mathrm{p}}\right)}{1+\bar{\beta}+c_{\mathrm{w}} \bar{T}_{\mathrm{s}} \bar{\lambda}^{-1}},
$$

where $E_{\mathrm{B}}$ is the monthly mean and terms with overbars are monthly means of daily values (themselves averages computed from hourly data). Following the work of dos Reis and Dias (1998) and Lenters et al. (2005), we compute the Bowen ratio using the formula (Webb, 1960, 1964)

$\bar{\beta}=\bar{\gamma} \frac{\overline{U\left(T_{\mathrm{s}}-T_{\mathrm{a}}\right)}}{\overline{U\left(e_{\mathrm{s}}-e_{\mathrm{a}}\right)}}$,

where $T_{\mathrm{a}}$ is the air temperature in ${ }^{\circ} \mathrm{C}, e_{\mathrm{a}}$ is the vapour pressure of air $2 \mathrm{~m}$ above the lake in $\mathrm{Pa}, e_{\mathrm{s}}$ is the vapour pressure of saturated air at the water surface temperature in $\mathrm{Pa}, U$ is the wind speed $2 \mathrm{~m}$ above the lake in $\mathrm{m} \mathrm{s}^{-1}$, and

$\bar{\gamma}=\frac{\bar{p}_{\mathrm{a}} c_{\mathrm{a}}}{0.622 \bar{\lambda}}$,

where $c_{\mathrm{a}}$ is the specific heat of air (assumed constant at $1011 \mathrm{~J} \mathrm{~kg}^{-1} \mathrm{~K}^{-1}$ ), and $p_{\mathrm{a}}$ is the atmospheric pressure in $\mathrm{Pa}$. The saturated vapour pressure at the water surface $\left(e_{\mathrm{s}}\right)$ and the vapour pressure in the atmosphere $\left(e_{\mathrm{a}}\right)$ are calculated using Buck's equations (Buck, 1981):

$e_{\mathrm{s}}=100\left(1.0007+3.46 \times 10^{-6} p_{\mathrm{a}}\right) 6.1121 e^{\frac{17.502 T_{\mathrm{s}}}{240.97+T_{\mathrm{s}}}}$,

and

$e_{\mathrm{a}}=\frac{\mathrm{RH}}{100} e_{\mathrm{s}}$,

where RH is the relative humidity.

\subsection{The Penman equation}

The Penman equation is used to estimate monthly evaporation from an open water body by the sum of a radiative and an aerodynamic term (Shuttleworth, 1993),

$E_{\mathrm{P}}=\frac{\Delta \bar{R}_{\mathrm{net}}+6.43 \gamma(1+0.536 \bar{U}) \overline{\mathrm{VPD}}}{(\Delta+\bar{\gamma})}$,

where VPD is the vapour pressure deficit at air temperature $2 \mathrm{~m}$ above the surface, $\Delta$ is the slope of the vapour pressure temperature curve $\left(\mathrm{kPa}^{\circ} \mathrm{C}^{-1}\right)$, and $\gamma$ is the psychometric constant $\left(\mathrm{kPa}^{\circ} \mathrm{C}^{-1}\right)$.

\subsection{Lake water balance}

A simplified water balance for the lake can be expressed as

$\Delta V=P-E+Q_{\mathrm{s}}-Q_{\mathrm{g}}$, where $\Delta V$ is the change in lake volume over the period $\Delta t$, $P$ is precipitation over the lake surface, $E$ is evaporation, $Q_{\mathrm{s}}$ is surface runoff water inflow, and $Q_{\mathrm{g}}$ is the net water inflow from groundwater exchanges estimated from deep percolation beneath the lake as a function of the lake area. The rainfall-runoff model $\left(Q_{\mathrm{s}}\right)$ has been re-calibrated on the basis of the 6 years of observations (Niedda et al., 2014).

\section{Results and discussion}

\subsection{Meteorological conditions}

Figure 3 shows mean daily (and 14-day moving average) net radiation, lake surface and air temperatures, difference between saturated water vapour and water vapour in the atmosphere, vapour pressure deficit (VPD), wind speed, the product of wind speed with the difference between lake and air temperature, and the product of wind speed with the difference between saturated water pressure and water vapour pressure in air.

Net radiation, $R_{\text {net }}$, shows strong seasonality, with a minimum daily value of $-58 \mathrm{~W} \mathrm{~m}^{-2}$ in November, a maximum of $228.5 \mathrm{~W} \mathrm{~m}^{-2}$ in June, and an annual mean of $88.8 \mathrm{~W} \mathrm{~m}^{-2}$. Daily variations of net radiation are high during spring due to shifting weather patterns and cloud cover. Variations are significantly smaller in winter and also in summer when meteorological conditions are more stable. Lake temperature also shows strong seasonality with an annual mean of $19.2^{\circ} \mathrm{C}$, a minimum of $7.7^{\circ} \mathrm{C}$ in February, and a maximum $29.7^{\circ} \mathrm{C}$ in July. Similarly, air temperature ranges from $2.6^{\circ} \mathrm{C}$ in February to $29.4^{\circ} \mathrm{C}$ in September with an annual mean of $16.6^{\circ} \mathrm{C}$. Both minima and maxima in lake and air temperature are shifted forward about 1 month from the net radiation minimum and maximum. Following patterns of lake and air temperature, $\left(e_{\mathrm{s}}-e_{\mathrm{a}}\right)$ and VPD minima and maxima are also shifted forward about a month from net radiation. Annual average wind speed is $2.3 \mathrm{~m} \mathrm{~s}^{-1}$ with large variations and peaks (maximum of $10.4 \mathrm{~m} \mathrm{~s}^{-1}$ on 6 January 2012) in winter and late fall.

\subsection{Heat budget and evaporation}

Evaporation estimated using BREB was on average $950 \mathrm{~mm} \mathrm{day}^{-1}$. The monthly means for terms of the heat budget (net radiation, evaporation, sensible heat, heat storage, and Bowen ratio, see Eqs. 7 and 8) are given in Table 1 for all 37 months of the survey period (July 2011 to July 2014).

Monthly evaporation, $E_{\mathrm{B}}$, shows strong seasonality ranging from $16.90 \mathrm{~W} \mathrm{~m}^{-2}$ in winter to $143.40 \mathrm{~W} \mathrm{~m}^{-2}$ in summer (almost a factor of 9 difference) with a mean of $76.20 \mathrm{~W} \mathrm{~m}^{-2}$ similar to other measurements in the Mediterranean region (e.g. Bouin et al., 2012). Seasonal trends of net radiation $\bar{R}_{\text {net }}$ follow the same seasonal patterns as that of evaporation. $\bar{R}_{\text {net }}$ ranges from 1.33 to $184.88 \mathrm{~W} \mathrm{~m}^{-2}$ with a mean of $90.16 \mathrm{~W} \mathrm{~m}^{-2}$ (see also Fig. 3a). In contrast to evapo- 

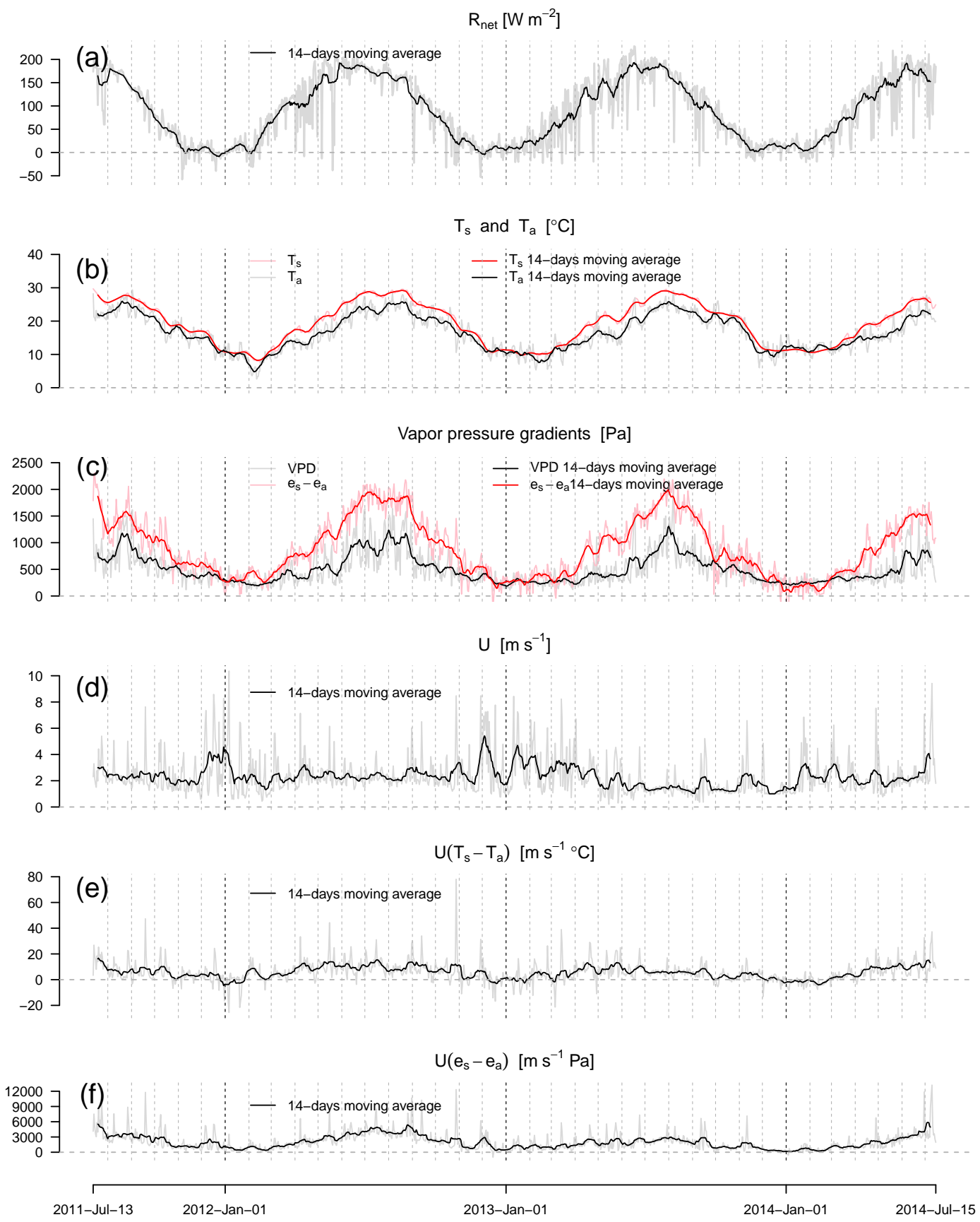

Figure 3. Time series of 14-day moving average (dark-colour lines) and mean daily (light-colour lines) of (a) net radiation, $R_{\text {net }}$, (b) lake surface $\left(T_{\mathrm{S}}\right.$, red $)$ and air $\left(T_{\mathrm{a}}\right.$, black) temperatures, (c) difference between saturated water vapour and water vapour in the atmosphere $\left(e_{\mathrm{S}}-e_{\mathrm{a}}\right.$, red) and vapour pressure deficit $\left(e_{\mathrm{a}}-\mathrm{RHe}_{\mathrm{a}}\right.$, black), (d) wind speed $U$, (e) the product of wind speed with the difference between lake and air temperature $U\left(T_{\mathrm{S}}-T_{\mathrm{a}}\right)$, and (f) the product of wind speed with the difference between saturated water vapour and air vapour pressure $U\left(e_{\mathrm{s}}-e_{\mathrm{a}}\right)$.

ration which dominates the heat budget, monthly sensible heat, $\bar{H}$, is smaller, ranging from $-11.49 \mathrm{~W} \mathrm{~m}^{-2}$ in winter to $33.26 \mathrm{~W} \mathrm{~m}^{-2}$ in early summer. Negative values of $H$ in January and also in February 2014 are due to negative values of the Bowen ratio $\bar{\beta}$ linked to periods when air temperature exceeded lake surface temperature (see Fig. 3b). Monthly values of $\bar{\beta}$ vary between -0.34 in February 2014 to 0.40 in February 2012 with a mean of 0.16 . The mean is similar to other water bodies in Mediterranean environment (e.g. Gallego-Elvira et al., 2010; Bouin et al., 2012), lower than lakes located in middle to high-latitudes (e.g. Lenters et al., 2005) but higher than subtropical lakes (e.g. Wang et al., 

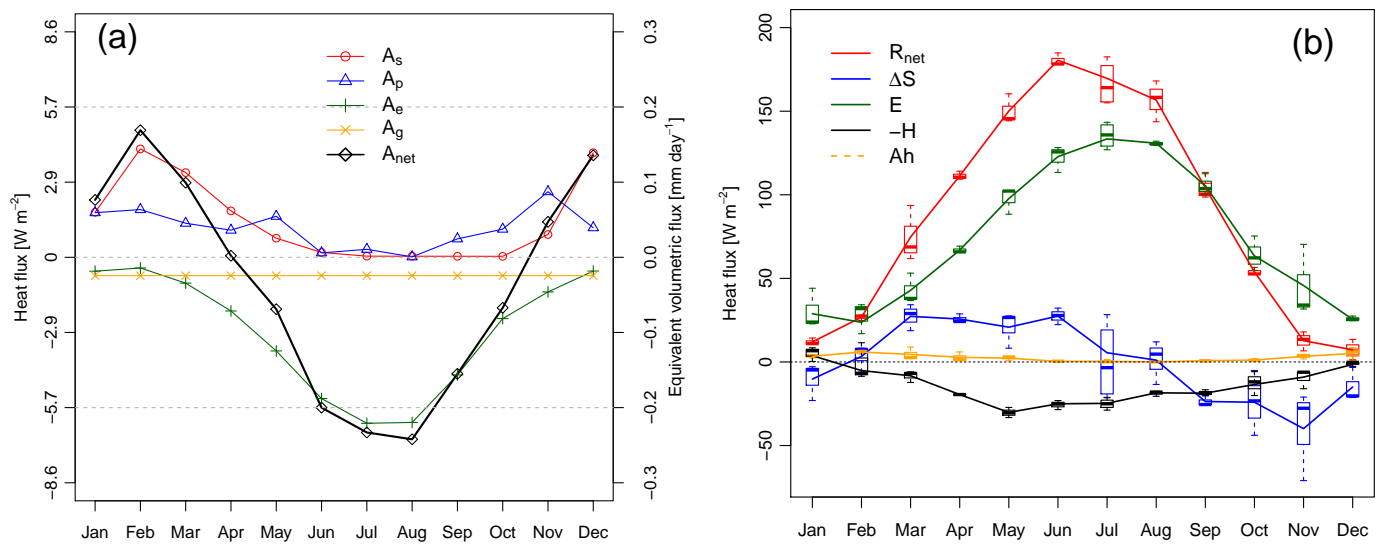

Figure 4. Monthly mean of (a) advected terms and (b) main components of the heat budget. In (b) the box indicates the range of the upper and lower quartiles with the median shown using bold horizontal line and the minimum and maximum shown with notches; line segments go through mean values.

2014). Except for the strongly negative values observed in January (and sometimes in February), $\bar{\beta}$ still shows significant variability $(0.05$ to 0.4$)$. Neglecting the wind correction factor (Webb, 1964) in the Bowen ratio (as in Bowen, 1926; Brutsaert, 1982) impacts estimates of monthly evaporation only in winter when evaporation is low but has negligible effect on the total yearly evaporation (see Appendix B).

Heat storage $(\overline{\Delta S})$ is positive (heat sink) usually from February to July or August when net radiation exceeds evaporation. The lake then acts as a heat source in the fall and early winter. A large negative value of $\overline{\Delta S}=-70.98 \mathrm{~W} \mathrm{~m}^{-2}$ was observed in November 2013 after an unusually warm month of October followed by a rapid cooling of the atmosphere in November due to dry windy conditions caused by the Mistral (see Fig. 3b and d).

Figure 4 shows annual monthly means of the different terms in the heat budget equation. Data allowed a precise evaluation of the different advection terms in the heat budget equation (Fig. 4a). Net groundwater heat flux $\left(\bar{A}_{\mathrm{g}}\right)$ was not included in our energy budget in Eq. (2) but an estimate using the lake water balance (see Sect. 3.3) indicates an average value of $0.7 \mathrm{~W} \mathrm{~m}^{-2}$, a negligibly small component of advection. Net advected heat is dominated by advected evaporation $\left(\bar{A}_{\mathrm{e}}\right)$ in summer and fall and by water input $\left(\bar{A}_{\mathrm{h}}=\bar{A}_{\mathrm{i}}+\bar{A}_{\mathrm{p}}\right.$, runoff plus precipitation) in winter. Maximum net advected flux in August is $-0.24 \mathrm{~mm} \mathrm{day}^{-1}$, a negligible value in the total heat budget. Heat advected by surface runoff $\left(\bar{A}_{\mathrm{s}}\right)$, a term that enters the equation for evaporation (Eq. 5), is small in comparison to other terms, as found in numerous other lake energy budget studies (e.g. Krabbenhoft et al., 1990; Sturrock et al., 1992; Winter et al., 2003; Lenters et al., 2005).

In early spring (February-March), net radiation increases more rapidly than evaporation (Fig. 4b): most of the radiation is used to warm up the lake (increase in heat storage, $\overline{\Delta S}$ ) and the remainder goes into evaporation. Then, starting in March, evaporation increases rapidly and reaches a maximum of $140 \mathrm{~W} \mathrm{~m}^{-2}$ in July. In the spring through summer, about $20 \mathrm{~W} \mathrm{~m}^{-2}$ is lost by sensible heat with a peak in May of $30.4 \mathrm{~W} \mathrm{~m}^{-2}$ when air and lake temperature difference is maximum (see Fig. 3b). Heat transfer between the air and the lake is small until March. The increase in sensible heat over the spring is faster than the decrease in fall. During spring and summer, most of the radiation is used for evaporation, with only smaller amounts for warming the lake and the air. Net cooling starts when net radiation becomes less than evaporation in September and energy for evaporation now comes from the release of heat storage. Heat storage $(\overline{\Delta S})$ is positive (net warming) from March to June and negative from September to February.

\subsection{Seasonal cycles}

The heat storage in the lake is an important component of the energy balance and shows strong seasonality. Heat storage is driven by net radiation but controlled by sensible heat exchange between lake water and air and thus by lake water dynamics and mixing. Water movement is driven by variations in the density of water (convection). The warmest, lessdense layers remain at the top while cooler water sinks. Figure 5 shows the evolution of lake temperature with depth for all months of the survey period. At this latitude warming starts in February or early March while cooling begins in August or September. During warming, the temperature of the surface layers rises rapidly. In summer, the thermocline is well defined at about $4-6 \mathrm{~m}$ above the lake bottom. By September, the lake is isothermal and cooling takes place through a uniform decrease in temperature at all depths over the fall. Mixing of lake waters occurs during cold spells associated with stormy and windy conditions in the fall. Note that the September 2013 through April 2014 data shown in Fig. 5 reflect the assumption that all layers are at the same 


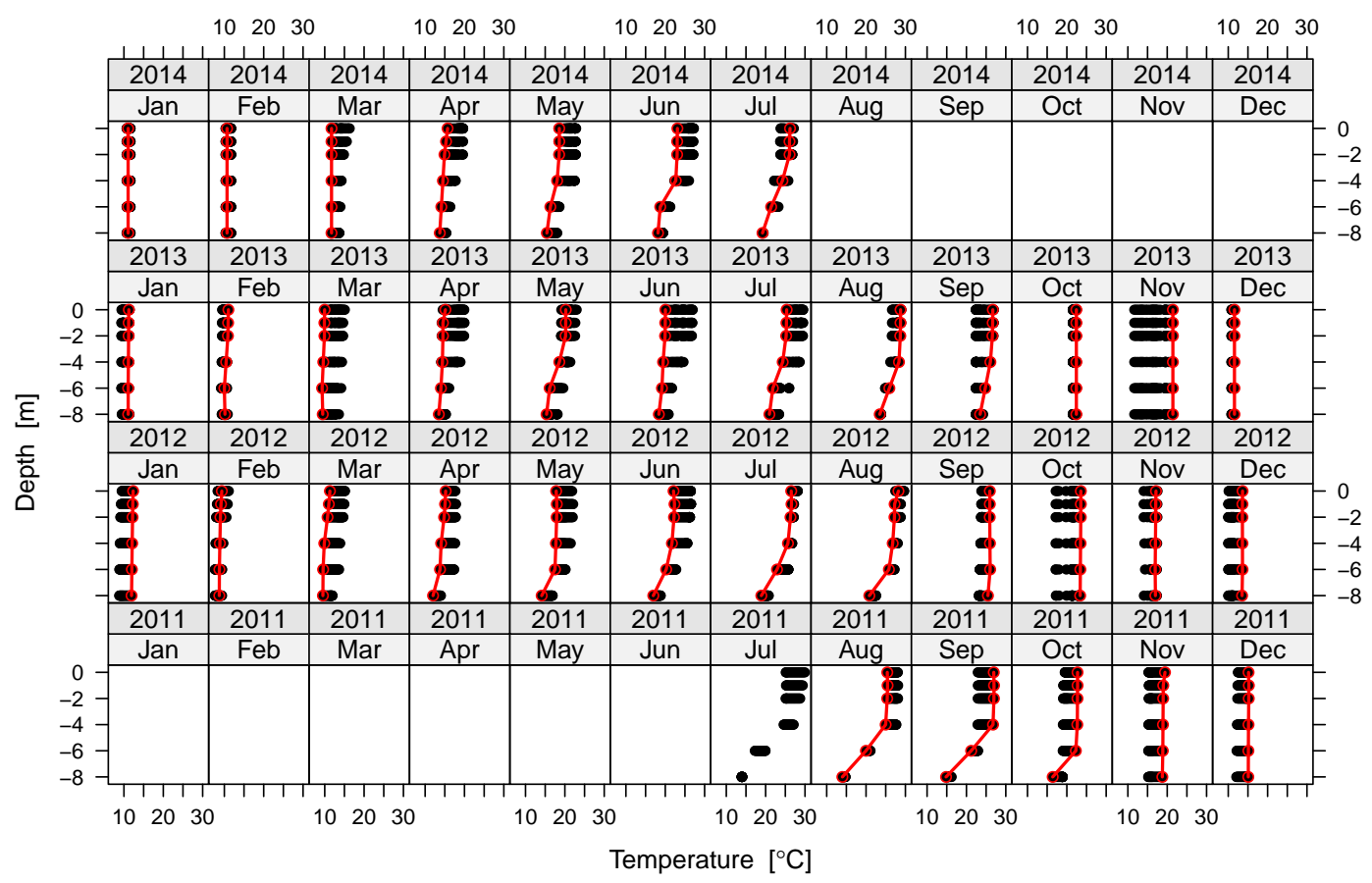

Figure 5. Lake temperature profiles. Black circles are daily average temperatures. Red circles represent the temperature profile on the first of the month.

temperature given by the bottom thermistor (the only temperature measurement working during that time). This assumption is based on the 2011 and 2012 record where temperatures at each depth indicated isothermal conditions. In November 2013, the temperature in the lake decreased by a record $11^{\circ} \mathrm{C}$ after cold windy Mistral conditions followed a warm month of October. It is this rapid decrease in temperature that caused an exceptionally high loss in heat storage (see previous section).

Figure 6 shows correlations between various terms of the heat budget equation. Evaporation is strongly influenced by net radiation $\left(r^{2}=0.83\right.$, Fig. $\left.6 a\right)$ but a clear seasonal pattern emerges resulting in a counterclockwise hysteresis loop. Evaporation in the spring is lower by about $40 \mathrm{~W} \mathrm{~m}^{-2}$ than in the fall for the same net monthly radiation.

Evaporation is highest in August while net radiation reaches its maximum in July. Evaporation is lowest in February when net radiation is smallest. The hysteresis in evaporation is likely due to the dependence of evaporation on the seasonal variations of $U\left(e_{\mathrm{s}}-e_{\mathrm{a}}\right)$ (Fig. $\left.6 \mathrm{~b}, r^{2}=0.78\right)$ which is considerably higher in the fall than in the spring (see also Fig. 3c) and also to a lesser extent to the variations of $U\left(T_{\mathrm{s}}-T_{z}\right)$ (Fig. 6c, $r^{2}=0.6$; see also Fig. 3b).

Sensible heat also shows a seasonal correlation with net radiation $\left(r^{2}=0.72\right.$, Fig. $\left.6 \mathrm{~d}\right)$ but the correlation is more complex and linked to difference in air and lake temperature (Fig. 6f, $r^{2}=0.86$ ) more so than to the latent heat flux (Fig. 6e, $r^{2}=0.55$ ). The hysteresis loop of sensible heat vs. radiation, shaped like an inclined number eight, has a steep ascending branch in the spring when the temperature difference between the air and the lake is highest. In the fall, when the lake and air temperatures are not as different, sensible heat decreases more slowly as net radiation decreases rapidly. This seasonal difference, due to the temperature difference between the air and the lake, originates from the lake water dynamics: while spring temperatures increase non-uniformly across the lake depth to form a well-defined thermocline at about 4-6 $\mathrm{m}$ above the lake bottom, the decrease in lake temperature is uniform in the fall due to sinking of surface waters and overturning by wind (see Fig. 5). Thus, the lake water dynamics and lake temperature cycle have a significant effect on global heat fluxes.

Although sensible heat is well correlated to the temperature difference between lake and air (Fig. 6f), it shows no correlation with heat storage $\left(r^{2}=0.05\right.$, Fig. 6h). Figure $6 \mathrm{~h}$, however, clearly illustrates the large seasonal difference in sensible heat at equivalent values of heat storage.

Another hysteresis loop is also evident in the relation between evaporation and heat storage (Fig. 6g). Maximum positive values of heat storage in the spring $\left(\sim 20 \mathrm{~W} \mathrm{~m}^{-2}\right)$ are associated with rising evaporation as net radiation increases (see Fig. 6a). As net radiation decreases in the fall, heat storage decreases rapidly and becomes negative $\left(-20 \mathrm{~W} \mathrm{~m}^{-2}\right)$ starting in September. Heat loss through the fall continues as evaporation further decreases to the lowest values in the winter time. Note that evaporation decreases more rapidly in the fall than it increases in the spring (see Fig. 3a). Then, in winter (January and February) when radiation again increases 

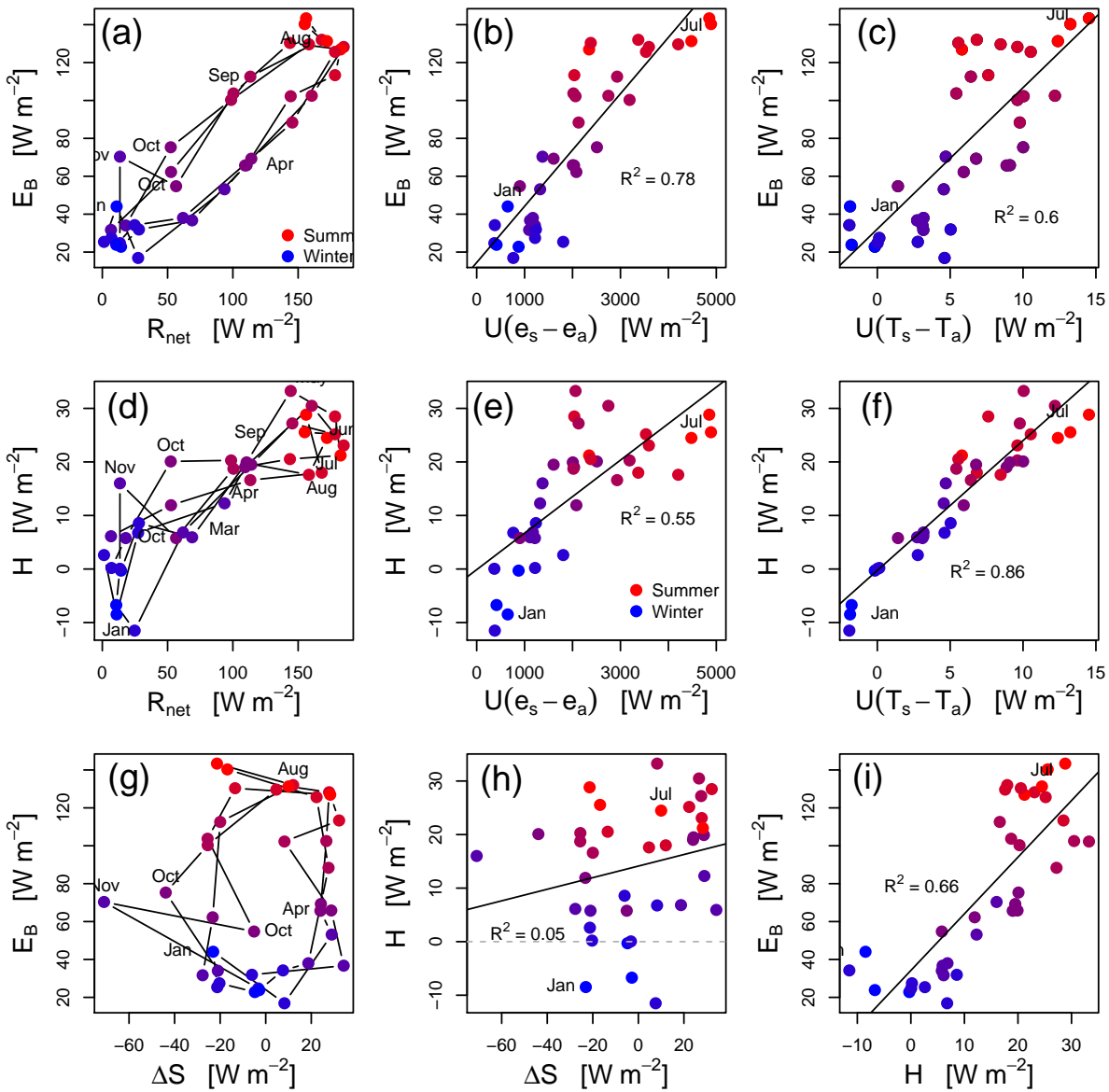

Figure 6. Correlations between various components of the heat budget equation. Dots represent monthly data over the 3-year survey period. Dot colour indicates the season (with red in summer and blue in winter). When seasonal cycles are apparent, line segments link successive data points.

rapidly but evaporation only slightly, heat storage becomes positive, closing the loop. The difference in heat storage between spring and fall is significant, of the order of $60 \mathrm{~W} \mathrm{~m}^{-2}$. Heat storage is an important component of the overall heat budget that cannot be neglected.

At a monthly scale, evaporation and sensible heat are relatively well correlated $\left(r^{2}=0.66\right.$, Fig. $\left.6 i\right)$. The slope of the linear fit yields a monthly Bowen ratio of 0.33 .

\subsection{Comparison between BREB and Penman equation}

Figure 7 shows monthly mean evaporation estimated using Penman's equation with the values of the radiative and aerodynamic terms (see Eq. 12). Like with calculations using BREB, radiation dominates evaporation with a maximum value in June of $125.5 \mathrm{~W} \mathrm{~m}^{-2}$. The aerodynamic term has low variability over the year with an average of $28 \mathrm{~W} \mathrm{~m}^{-2}$.

Figure $8 \mathrm{a}$ and $\mathrm{b}$ show the monthly mean differences between BREB and Penman's values. The monthly mean and standard deviation of BREB are 2.59 and $1.47 \mathrm{~mm} \mathrm{day}^{-1}$, respectively. They are 3.06 and $1.83 \mathrm{~mm} \mathrm{day}^{-1}$, respectively, for Penman. At an annual scale BREB is $950 \mathrm{~mm} \mathrm{day}^{-1}$, $15 \%$ less than Penman's value of $1121 \mathrm{~mm} \mathrm{day}^{-1}$ (or Penman is $18 \%$ higher than BREB). The difference between Penman and BREB displays seasonal variability ranging from a maximum of $1.27 \mathrm{~mm} \mathrm{day}^{-1}$ in the June to a minimum of $0.52 \mathrm{~mm} \mathrm{day}^{-1}$ in November. The highest percentage difference values between Penman and BREB are in November (Penman is $38 \%$ lower than BREB) and in March (Penman is $60 \%$ higher than BREB). The highest percentage difference values between BREB and Penman are in March (BREB is $38 \%$ lower than Penman) and in November (BREB is $48 \%$ higher than Penman).

Table 1, which gives both evaporation values for BREB and Penman, can help explain the seasonality difference between the two calculations. In spring, part of the incoming energy as solar radiation is absorbed by water as heat storage and a smaller fraction of radiation is used for evaporation. Because Penman's method does not take into account heat storage, it overestimates evaporation. For example, in March 2013 (Table 1), about $69 \mathrm{~W} \mathrm{~m}^{-2}$ comes as net radiation of which about $34 \mathrm{~W} \mathrm{~m}^{-2}$ is absorbed by water (heat 
Table 1. Monthly evaporation for BREB and Penman with other terms of the heat budget and Bowen ratio. Units are $\mathrm{W} \mathrm{m}^{-2}$.

\begin{tabular}{|c|c|c|c|c|c|c|c|}
\hline & Month & BREB & Penman & $R_{\text {net }}$ & $\Delta S$ & $H$ & $\beta$ \\
\hline 1 & Jul 2011 & 143.40 & 151.53 & 156.10 & -21.40 & 28.83 & 0.20 \\
\hline 2 & Aug 2011 & 132.00 & 163.28 & 168.08 & 12.04 & 18.00 & 0.14 \\
\hline 3 & Sep 2011 & 112.60 & 118.41 & 113.38 & -19.99 & 16.60 & 0.15 \\
\hline 4 & Oct 2011 & 62.30 & 65.77 & 52.65 & -23.29 & 11.92 & 0.19 \\
\hline 5 & Nov 2011 & 31.70 & 25.67 & 6.66 & -27.68 & 6.13 & 0.19 \\
\hline 6 & Dec 2011 & 25.40 & 37.11 & 1.33 & -21.29 & 2.61 & 0.10 \\
\hline 7 & Jan 2012 & 44.10 & 28.92 & 10.97 & -23.07 & -8.47 & -0.19 \\
\hline 8 & Feb 2012 & 16.90 & 31.25 & 27.44 & 8.21 & 6.77 & 0.40 \\
\hline 9 & Mar 2012 & 53.10 & 80.66 & 93.61 & 28.97 & 12.27 & 0.23 \\
\hline 10 & Apr 2012 & 65.70 & 94.82 & 109.36 & 24.02 & 19.02 & 0.29 \\
\hline 11 & May 2012 & 102.50 & 131.16 & 160.42 & 26.61 & 30.48 & 0.30 \\
\hline 12 & Jun 2012 & 128.20 & 171.57 & 184.88 & 27.82 & 23.08 & 0.18 \\
\hline 13 & Jul 2012 & 131.30 & 165.71 & 172.09 & 10.00 & 24.48 & 0.19 \\
\hline 14 & Aug 2012 & 129.60 & 164.15 & 158.28 & 4.68 & 17.60 & 0.14 \\
\hline 15 & Sep 2012 & 100.30 & 101.96 & 98.66 & -25.46 & 20.29 & 0.20 \\
\hline 16 & Oct 2012 & 75.30 & 63.55 & 52.43 & -43.89 & 20.10 & 0.27 \\
\hline 17 & Nov 2012 & 34.00 & 34.89 & 17.96 & -21.02 & 5.78 & 0.17 \\
\hline 18 & Dec 2012 & 27.40 & 34.32 & 7.01 & -20.33 & 0.20 & 0.01 \\
\hline 19 & Jan 2013 & 22.80 & 32.08 & 14.33 & -4.77 & -0.29 & -0.01 \\
\hline 20 & Feb 2013 & 31.90 & 39.68 & 28.03 & -6.05 & 8.58 & 0.27 \\
\hline 21 & Mar 2013 & 36.70 & 63.80 & 68.78 & 34.22 & 5.93 & 0.16 \\
\hline 22 & Apr 2013 & 65.90 & 92.46 & 110.51 & 28.77 & 19.92 & 0.30 \\
\hline 23 & May 2013 & 102.20 & 112.19 & 144.30 & 8.23 & 33.26 & 0.33 \\
\hline 24 & Jun 2013 & 113.30 & 144.86 & 178.25 & 32.21 & 28.50 & 0.25 \\
\hline 25 & Jul 2013 & 126.90 & 163.39 & 182.51 & 28.30 & 21.21 & 0.17 \\
\hline 26 & Aug 2013 & 130.40 & 137.64 & 143.71 & -13.45 & 20.53 & 0.16 \\
\hline 27 & Sep 2013 & 103.70 & 98.10 & 100.44 & -25.51 & 18.73 & 0.18 \\
\hline 28 & Oct 2013 & 54.80 & 60.24 & 56.53 & -5.11 & 5.78 & 0.11 \\
\hline 29 & Nov 2013 & 70.30 & 32.22 & 13.51 & -70.98 & 16.01 & 0.23 \\
\hline 30 & Dec 2013 & 24.70 & 22.51 & 13.48 & -3.27 & 0.05 & 0.00 \\
\hline 31 & Jan 2014 & 23.80 & 23.09 & 10.69 & -2.86 & -6.72 & -0.28 \\
\hline 32 & Feb 2014 & 34.20 & 31.94 & 24.77 & 7.59 & -11.49 & -0.34 \\
\hline 33 & Mar 2014 & 38.00 & 60.91 & 61.84 & 18.71 & 6.83 & 0.18 \\
\hline 34 & Apr 2014 & 69.30 & 92.66 & 114.13 & 24.21 & 19.49 & 0.28 \\
\hline 35 & May 2014 & 88.40 & 114.93 & 145.55 & 27.57 & 27.20 & 0.31 \\
\hline 36 & Jun 2014 & 125.70 & 161.12 & 178.24 & 22.31 & 25.17 & 0.20 \\
\hline 37 & Jul 2014 & 140.30 & 155.52 & 155.03 & -16.82 & 25.55 & 0.18 \\
\hline
\end{tabular}

storage) and about $36 \mathrm{~W} \mathrm{~m}^{-2}$ (52\% of net radiation) as evaporation (BREB). In Penman formula, all $64 \mathrm{~W} \mathrm{~m}^{-2}$ is used for evaporation.

In winter, the difference between BREB and Penman is lower and can become negative (Fig. 8) because the process described above is reversed: the heat stored in the lake serves as a heat source and provides additional energy for evaporation. For example, in November 2013, net radiation is only $13 \mathrm{~W} \mathrm{~m}^{-2}$. Evaporation is $70 \mathrm{~W} \mathrm{~m}^{-2}$, about the same value of energy lost by lake, while sensible heat is $16 \mathrm{~W} \mathrm{~m}^{-2}$ (loss). Penman's method grossly underestimates evaporation $\left(13 \mathrm{~W} \mathrm{~m}^{-2}\right)$. This result underlines the effect and importance of seasonality and heat storage in lakes in a Mediterranean climate.
When comparing BREB and Penman's methods, it is clear that the differences originate from neglecting heat storage $(\Delta S)$ in Penman's method (Eq. 12). The greater this term is, the greater the difference between the two methods. Since its value varies according to seasons, so does the difference between BREB and Penman. Thus, the seasonal difference between BREB and Penman could serve as an indicator of the importance of heat storage in different types of lakes under different climatic conditions (see Sect. 3.6).

As stated in our introduction, theoretically the net radiation term in Penman's equation (Eq. 7) should be replaced with the net available energy (Brutsaert, 1982; Shuttleworth, 1993) - the net radiation minus the heat storage. Re-computing evaporation using Penman's equation and subtracting the heat storage only changes monthly values of 


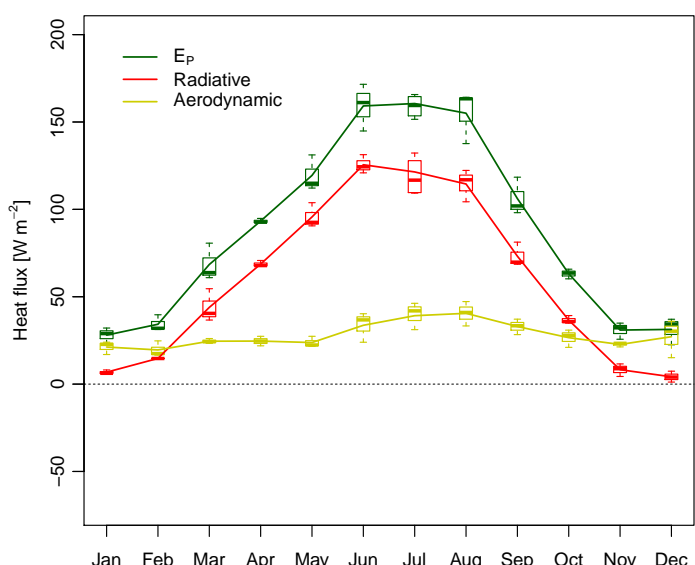

Figure 7. Monthly mean evaporation, $E_{\mathrm{P}}$, with radiative and aerodynamic terms for the Penman equation. Meaning of boxes, line segments, and notches are defined in the caption of Fig. 4.

evaporation shifting the monthly evaporation curves (Fig. 7) to the right, decreasing evaporation in the spring and increasing it in the fall (up to $78 \%$ difference at most). The net yearly evaporation, however, remains identical (less than $0.3 \%$ difference).

\subsection{Lake water balance}

Water follows two main pathways. Water input, runoff and precipitation are concentrated during a short cool wet season from about November to March. Water losses, mainly by evaporation, occur throughout the year but are highest in summer. The annual volumetric lake water balance is shown in Table 3 as an update to the table presented in Niedda and Pirastru (2012). In Table 3, all terms in Eq. (13) are estimated from measurements and hence $\Delta V$ is estimated directly (measured with a piezometer) and also indirectly (from the sum of the terms on the right-hand side of Eq. 13). The residual is the difference between the two estimates of $\Delta V$. We estimate the groundwater term $Q_{\mathrm{g}}$ in Eq. (13) to be $1.5 \mathrm{~mm}$ day $^{-1}$ based on the work of Niedda et al. (2014).

Evaporation is calculated using the Penman equation for the first 3 years and the energy budget method thereafter (Niedda and Pirastru, 2012; Niedda et al., 2014). For the first 3 years, from September 2008 to September 2011, calculations use climatic data from the land station corrected for the difference between the land and raft station using a linear regression between data obtained during the period July 2011 to July 2014. Evaporation values are also corrected using a linear regression between Penman values and a simplified energy budget: $E_{\mathrm{B}}=R_{\text {net }}-H+\Delta S$, where $H$ is calculated as in Hartmann (1994) (see Niedda et al., 2014, for details). The (linear) relation between Penman and simplified energy budget has been calibrated on the period from July 2011 to July 2014. Then, for the water balance of the period from
September 2011 to September 2014, evaporation is calculated using the simplified energy budget.

The differences in evaporated volume at an annual scale between the simplified energy budget method and BREB is of the order of about $33 \times 10^{3} \mathrm{~m}^{3}$; the simplified method overestimates evaporation by about $0.2 \mathrm{~mm} \mathrm{day}^{-1}$. These values depend on the lake surface considered and seasonality (heat advection).

In Table 3, all terms in the lake water balance are of the same order of magnitude. In the first 3 years surface runoff is high because the rainfall-runoff model of Niedda and Pirastru (2012) overestimates water inflow into the lake for high values of runoff. This leads to a very large residual for the hydrological year 2009-2010. Rainfall and evaporation are not linked because they occur over different seasons. Also because soil moisture controls discharge, rainfall and discharge correlation depends on the temporal distribution of rainfall. Finally, the volumetric water balance depends on the lake surface area and the polynomial function needs to be carefully evaluated. The water balance in 2008 is calculated with an extremely low lake level (the lake was only $3 \mathrm{~m}$ deep) due to enduring dry conditions and thus with a smaller area that influences groundwater exchanges and evaporation.

\subsection{Comparison of evaporation by BREB and Penman for different climatic zones}

We compare six lakes (including Lake Baratz) in three different climatic zones for evaporation. For three African lakes (Ziway, Victoria, Bosumtwi), the study areas are classified as tropical savanna (Aw, wet and dry climate, Köppen-Geiger climate classification, Peel et al., 2007), since they are characterized by monthly mean temperatures that are over $18^{\circ} \mathrm{C}$ and a pronounced dry season in winter. The wet season is controlled by moist, warm equatorial air masses at the time of high sun elevation angle (summer monsoon season). The dry season is controlled by the continental tropical air masses at the time of lower sun elevation angle. Two North American lakes (Mirror and Williams lakes) are classified as humid continental (Dfb, warm summer subtype) characterized by an average temperature above $10^{\circ} \mathrm{C}$ with warmest months below $22^{\circ} \mathrm{C}$ and a coldest month average below $0{ }^{\circ} \mathrm{C}$. Precipitations occur year round. Finally, the Mediterranean climate (Lake Baratz) is classified as dry-summer subtropical (Csa), with an average temperature above $22{ }^{\circ} \mathrm{C}$ in the warmest months with hot and dry summers and with precipitation concentrated in the autumn and the spring.

Table 3 summarizes characteristics of these six lakes and gives the maximum monthly mean ratio of evaporation estimated by Penman's equation over that estimated by BREB. Details of how evaporation was estimated for the five lakes are given in Appendix C. Note that three papers compute the Penman equation and BREB using only net radiation (Shanahan et al., 2007; Vallet-Coulomb et al., 2001; Yin and Nicholson, 1998) neglecting heat storage altogether while two pa- 
Table 2. Annual components of the lake water balance for the five hydrological years. $P$ is precipitation, $E$ is evaporation by BREB, $Q_{\mathrm{s}}$ is surface runoff (inflow), $Q_{\mathrm{g}}$ is net groundwater flow, $\Delta V$ is the volume of the lake during the hydrological year, $\Delta h$ is the measured lake water level. Residuals represent the errors on closing the water balance.

\begin{tabular}{lrccccrr}
\hline $\begin{array}{l}\text { Hydrological } \\
\text { year }\end{array}$ & $\begin{array}{r}\Delta h \\
(\mathrm{~m})\end{array}$ & $\begin{array}{c}P \\
\left(10^{6} \mathrm{~m}^{3}\right)\end{array}$ & $\begin{array}{c}E \\
\left(10^{6} \mathrm{~m}^{3}\right)\end{array}$ & $\begin{array}{c}Q_{\mathrm{s}} \\
\left(10^{6} \mathrm{~m}^{3}\right)\end{array}$ & $\begin{array}{c}Q_{\mathrm{g}} \\
\left(10^{6} \mathrm{~m}^{3}\right)\end{array}$ & $\begin{array}{r}\Delta V \\
\left(10^{6} \mathrm{~m}^{3}\right)\end{array}$ & $\begin{array}{r}\text { Residual } \\
\left(10^{6} \mathrm{~m}^{3}\right)\end{array}$ \\
\hline $2008-2009$ & 2.75 & 0.165 & 0.289 & 0.971 & 0.144 & 0.610 & 0.094 \\
$2009-2010$ & 1.70 & 0.240 & 0.387 & 0.250 & 0.195 & 0.584 & -0.675 \\
$2010-2011$ & 2.65 & 0.328 & 0.503 & 1.595 & 0.235 & 1.092 & 0.093 \\
$2011-2012$ & -0.60 & 0.264 & 0.471 & 0.361 & 0.243 & -0.267 & 0.179 \\
$2012-2013$ & 0.21 & 0.329 & 0.465 & 0.494 & 0.239 & 0.091 & -0.029 \\
$2013-2014$ & -0.49 & 0.270 & 0.454 & 0.213 & 0.237 & -0.213 & -0.006 \\
\hline Sum & 6.22 & 1.596 & 2.569 & 3.884 & 1.293 & 1.897 & -0.344 \\
Mean & 1.04 & 0.266 & 0.428 & 0.647 & 0.215 & 0.316 & -0.057 \\
SD & 1.53 & 0.061 & 0.078 & 0.539 & 0.039 & 0.535 & 0.312 \\
\hline
\end{tabular}

Table 3. Comparison of BREB and Penman's method for six lakes in three different climatic zones. Climate type is based on Köpper classification. The ratio $E_{\mathrm{P}} / E_{\mathrm{B}}$ and the $\mathrm{SD}$ are calculated using the average monthly evaporation (see Appendix $\mathrm{C}$ for details).

\begin{tabular}{|c|c|c|c|c|c|c|c|c|}
\hline Lake & Latitude & Climate & $\begin{array}{l}\text { Surface area } \\
\mathrm{km}^{2}\end{array}$ & $\begin{array}{r}\text { Max depth } \\
\mathrm{m}\end{array}$ & $\begin{array}{c}\operatorname{Mean}\left(E_{\mathrm{P}} / E_{\mathrm{B}}\right) \\
\text { ratio }\end{array}$ & $\begin{array}{c}\max \left(E_{\mathrm{P}} / E_{\mathrm{B}}\right) \\
\quad \text { ratio }\end{array}$ & $\begin{array}{l}\text { Standard } \\
\text { deviation }\end{array}$ & $\begin{array}{l}\text { Number } \\
\text { of years }\end{array}$ \\
\hline Mirror & $43^{\circ} 37^{\prime} \mathrm{N}$ & Humid continental & 0.15 & 11 & 1.14 & 1.25 & 0.09 & $6^{\mathrm{a}}$ \\
\hline Williams & $45^{\circ} 48^{\prime} \mathrm{N}$ & Humid continental & 0.36 & 10 & 0.99 & 1.04 & 0.04 & $5^{\mathrm{a}}$ \\
\hline Bosumtwi & $6^{\circ} 30^{\prime} \mathrm{N}$ & Tropical wet and dry & 52.00 & 80 & 0.97 & 1.06 & 0.05 & $55^{\mathrm{b}}$ \\
\hline Ziway & $7^{\circ} 58^{\prime} \mathrm{N}$ & Tropical wet and dry & 440.00 & 9 & 1.05 & 1.14 & 0.05 & $26^{\mathrm{b}}$ \\
\hline Victoria & $1^{\circ} 00^{\prime} \mathrm{S}$ & Tropical wet and dry & 68800.00 & 92 & 1.13 & 1.19 & 0.04 & $22^{\mathrm{b}}$ \\
\hline Baratz & $40^{\circ} 40^{\prime} \mathrm{N}$ & Mediterranean & 0.45 & 10 & 1.19 & 1.60 & 0.25 & 3 \\
\hline
\end{tabular}

${ }^{a}$ Calculated for the ice-free season. May and October not available for all years. ${ }^{b}$ Limited climatic data available: e.g. air temperature, relative humidity and wind speed.

pers estimate heat storage and subtract it from the net radiation (Winter et al., 1995; Rosenberry et al., 2007). There is clearly no fixed standard and the use of the Penman equation energy term and of BREB estimates depends on the available data. To compare with these studies, we use Penman's evaporation for Lake Baratz computed by subtracting the heat storage term from the net radiation in the Penman equation (see Sect. 3.4).

Except for Lake Baratz, the maximum ratio of Penman's evaporation over BREB evaporation is slightly above 1 and Penman's method compares well with BREB (ratio equal or less than 1.25). For Lake Baratz, however, Penman's estimate is 1.6 times BREB and standard deviation is 1 order of magnitude higher than at other lakes. This difference motivates us to compare seasonal evaporation trends for different climatic zones.

Figure 9 shows monthly mean evaporation for the six lakes. Lakes in different climatic zones have distinct responses. The comparison with similar studies in other lakes allow us to analyse and explain why $\Delta S$ is seasonally variable and very high in the case of Lake Baratz (small Mediterranean lake), lower in the case of the North American (small) lakes, and even smaller and rather constant throughout the year in the case of the tropical African (large) lakes (Table 3).

For the North American and Mediterranean climates, the shapes of the evaporation curves are similar, with highs in the summer and lows in winter, but the range of evaporation is twice larger in the Mediterranean climate. In tropical Africa, lake evaporation is high year long and the shape of the evaporation curve shows an inverted trend due to the monsoon season.

Climate is not the only factor influencing the value of the ratio of Penman to BREB evaporation (Table 3). Lake dimensions (area, depth, volume) also play a role (Gorham and Boyce, 1989). Gorham (1964), analysing 71 lakes in a temperate climate, suggested that any shape effect is manifested chiefly in smaller lakes because the effects of varying area and depth are more pronounced. Moreover, layer mixing can influence the rate of heat storage significantly and consequently the rate of energy exchanges (Lewis, 1983).

In terms of water circulation both Lake Williams (LaBaugh et al., 1981) and Mirror Lake (Winter and Likens, 2009) are classified as dimictic, i.e. water mixing occurs twice a year and annual energy exchanges are limited in win- 

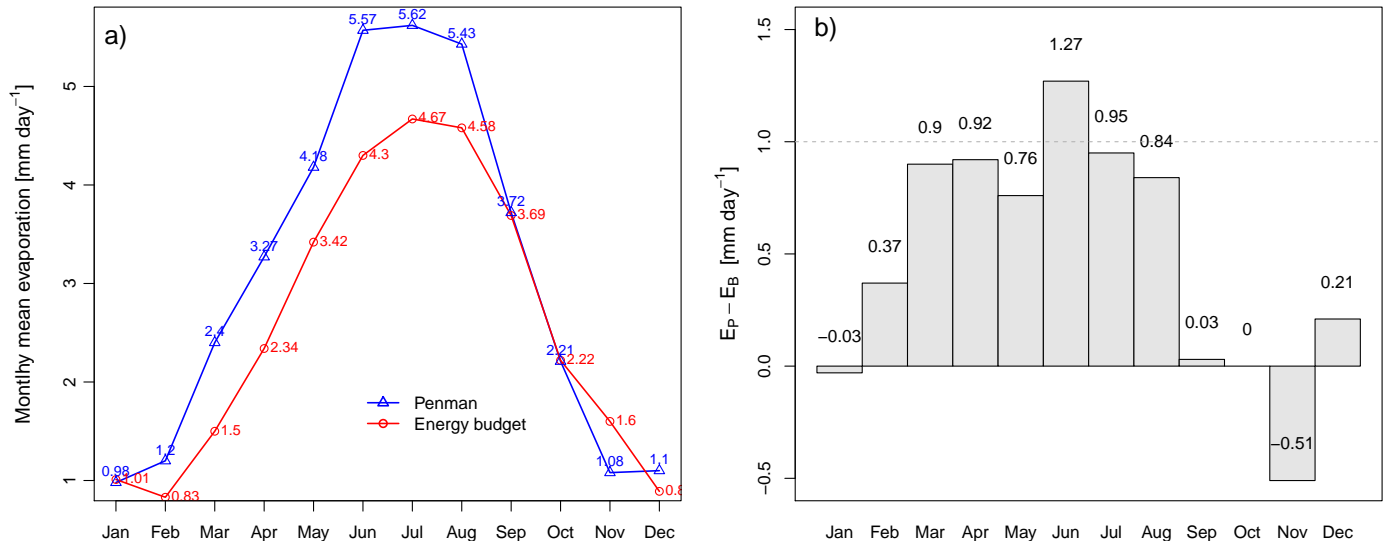

Figure 8. (a) Monthly mean evaporation. (b) Monthly mean difference between Penman, $E_{\mathrm{P}}$, and BREB evaporation, $E_{\mathrm{B}}$.

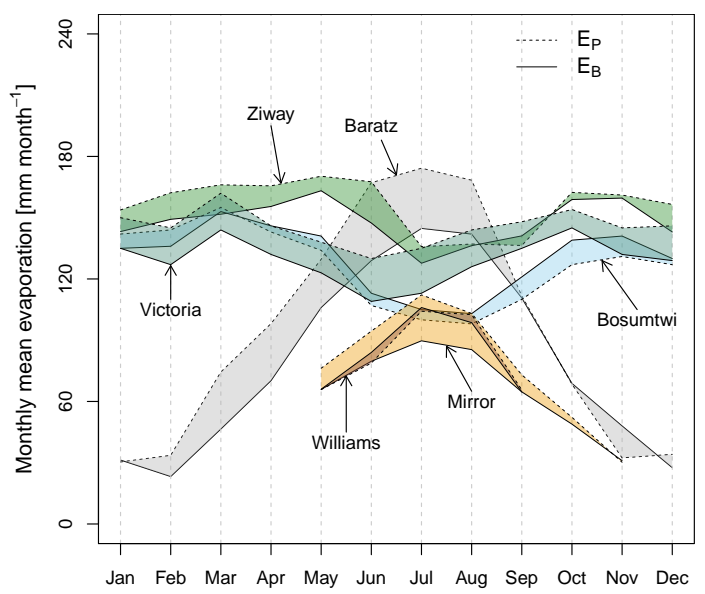

Figure 9. Monthly mean evaporation estimated using BREB and Penman's equation for six lakes in different climatic zones.

ter due to ice cover. Lake Baratz shows a monomictic behaviour, meaning that it never freezes, it is thermally stratified throughout much of the year (Fig. 5) and then mixes thoroughly each winter from top to bottom. Lake Bosumtwi is the only lake where BREB is higher than Penman with an almost constant ratio from March to December. Our hypothesis for Lake Bosumtwi is that the larger BREB value is a consequence of its small ratio of surface area to water depth, meromictic behaviour (Shanahan et al., 2007), which implies a stable layering (absence of mixing), and a release of energy during the monsoon season. Furthermore, for this lake, BREB is calculated using the simplified energy budget which we found can overestimate evaporation (see Sect. 3.5).

Figure 10 shows the cumulative error of monthly evaporation difference between BREB and Penman (decreasing trend means Penman estimation is higher than BREB). For two lakes (Williams and Victoria), the cumulative error is essentially a straight line indicating that the monthly evaporation difference is nearly constant and thus Penman's estimate

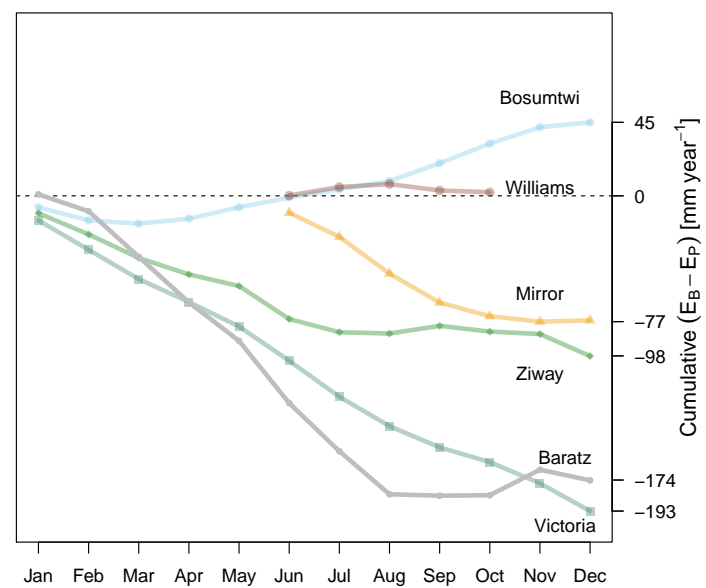

Figure 10. Annual cumulative bias on evaporation estimate (BREB minus Penman) for the six lakes.

of monthly evaporation can be corrected using a simple coefficient valid year-round.

In contrast, the seasonal difference between BREB and Penman at Lake Baratz or Mirror lake is clearly visible in the change of slope at the end of summer. In these cases, correction to Penman's formula is more difficult. For Williams Lake in continental North America, the effort to calculate evaporation rate using BREB does not seem justified given the small bias of Penman's method (Winter et al., 1995; Rosenberry et al., 2007). For cold places or where seasonal and interannual changes in temperature are small as in African lakes, changes in the energy stored in the lake can be neglected.

\section{Conclusions}

We estimate evaporation for Lake Baratz, a Mediterranean lake in Sardinia, Italy, using the energy budget method (BREB) and Penman's method relying on new measurements 
from a raft station over a period of 3 years. Evaporation occurs year-round with a maximum in July, a minimum in December, and an annual mean of $950 \mathrm{~mm} \mathrm{day}^{-1}$. Yearly evaporation estimated using Penman's method neglecting heat storage was $15 \%$ higher than with the energy budget method. At seasonal scales, Penman and the energy budget methods had cyclic differences ranging from $1.27 \mathrm{~mm} \mathrm{day}^{-1}$ in June to $0.52 \mathrm{~mm} \mathrm{day}^{-1}$ in November. Including heat storage in Penman's equation did not change the yearly estimate of evaporation. The most important factors controlling evaporation were net radiation and heat storage. In particular, the heat stored in the lake from early February and released in early fall biased upward evaporation estimates using Penman's equation. Convective heat transfer and water mixing affect the energy budget method making this method particularly sensitive to rapid decreases of heat storage during early fall. The net heat advection shows a marked seasonality but its effect is negligible for practical application $\left(<1 \mathrm{~W} \mathrm{~m}^{-2}\right.$ on average). Our results indicate that assessing the heat storage term in small water bodies in Mediterranean climate is very important. This term plays a fundamental role in controlling the rate of evaporation and cannot be neglected. A cyclic calibration of Penman should be done to reduce errors for practical and scientific applications. We also compared evaporation rates from our Mediterranean site with two other different hydro-climatic zones: continental North America and tropical Africa. In tropical Africa, BREB and Penman evaporation ratios for the three lakes are nearly constant despite large differences in lake area and lake depth. This is likely due to the lack of change of heat storage. In north American lakes the mean value of the difference is low probably because heat storage and evaporation are limited by the short open-water season. Our results highlight that basins in Mediterranean environments are particularly sensitive to climate variations due to the hot dry summer season, year-round open-water conditions, and limited rainfalls.
Our objective in this paper was to evaluate the Penman equation when data are scarce (no measure of heat storage) even though we have the data to correct the energy term. It is unfortunate that no papers address the issue of including or not the heat storage term (see 4; Brutsaert, 1982 or Shuttleworth, 1993). It seems that, from a theoretical standpoint, heat storage and other energy components are always considered but in practice they are usually neglected except in a few studies. Also, in the literature, there is a lack of sensitivity analysis with respect to the heat storage term in the Penman equation at different timescales, for different climates, and for different lake sizes. 


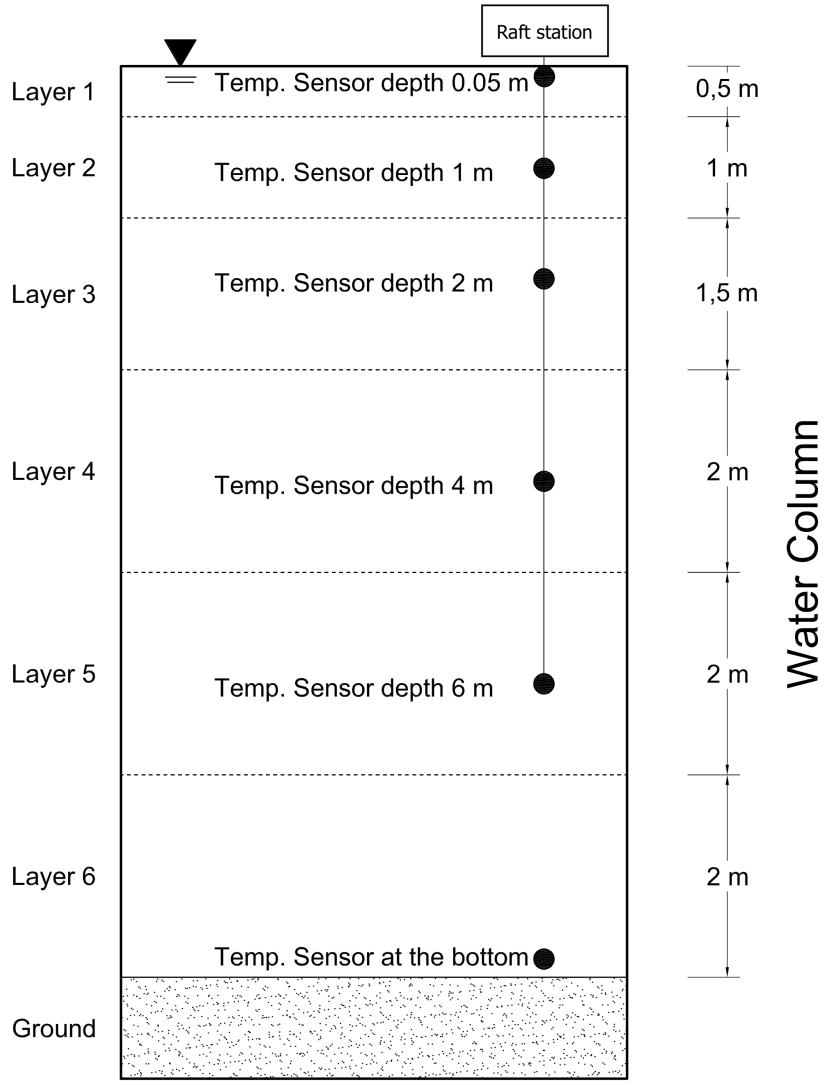

Figure A1. Layer thickness and temperature sensor locations (black circles). Sensors for layers 1, 2, 3, 4 and 5 are attached to the raft. The thickness of layer 6 varies with lake level and is taken into account in the calculation of the heat storage term (see Eq. 4).

\section{Appendix A: Lake water temperature measurements}

Figure A1 shows the position of the temperature sensors in the lake and the thickness of the layers used to compute the heat storage term.

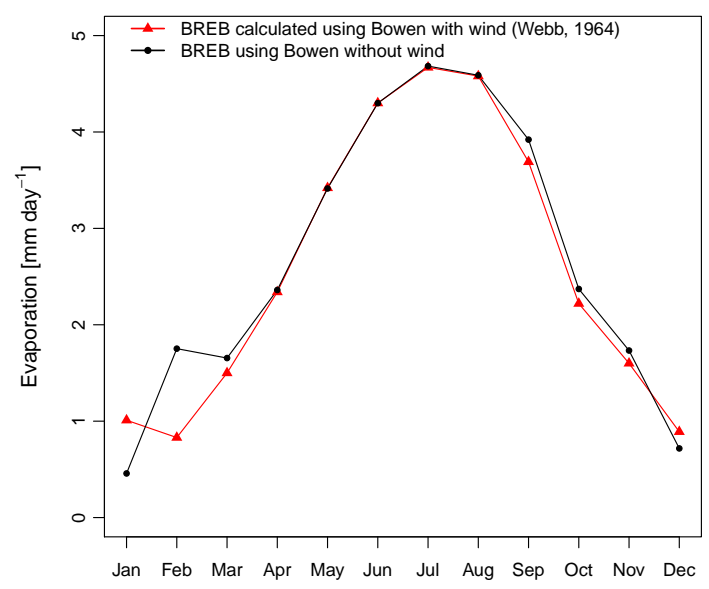

Figure B1. Monthly average of BREB evaporation computed with and without the effect of wind.

\section{Appendix B: Effect of the wind on the Bowen ratio}

We compared the Bowen ratio calculated with and without the wind. The wind correction for the Bowen ratio using Webb (1960) was found important only in winter due to peaks of wind during that season. Calculation of evaporation with and without wind also differ in winter (Fig. B1). Mean annual difference on evaporation is $0.07 \mathrm{~mm} \mathrm{day}^{-1}$ and standard deviation $0.33 \mathrm{~mm} \mathrm{day}^{-1}$, or, equivalently, an annual difference of $25 \mathrm{~mm} \mathrm{yr}^{-1}(2.6 \%)$. 


\section{Appendix C: Calculation of BREB for other lakes}

To estimate monthly mean evaporation for other lakes (Fig. 9) we made use of published data in the form of tables and graphs. For Lake Bosumtwi, data have been graphically estimated from Fig. 7 of Shanahan et al. (2007). The data from lake Ziway were taken form Table 2 of Vallet-Coulomb et al. (2001). The data of lake Victoria were obtained from Table 6 of Yin and Nicholson (1998). The data of BREB evaporation from June to October for Mirror Lake were obtained from Table 3 of Winter et al. (2003) while the values for May to November have been graphically estimated from Fig. 2 of Rosenberry et al. (2007). Penman values for this lake were estimated from their Fig. 3c. The data of BREB evaporation from Williams Lake were taken from Table 2 of Winter et al. (1995) while the Penman values were graphically estimated from Fig. 2a of the same paper.
Estimations of BREB often rely on few measurements and several assumptions. A common parameter neglected in tropical climate studies is the change in energy stored into the lake (Yin and Nicholson, 1998; Vallet-Coulomb et al., 2001; Shanahan et al., 2007) because of its assumed small seasonal and interannual variation. Also, water surface, air temperature and water pressure gradient are estimates, and a constant Bowen ratio is used (Yin and Nicholson, 1998; ValletCoulomb et al., 2001). Net radiation is sometimes also estimated (Yin and Nicholson, 1998; Shanahan et al., 2007; Vallet-Coulomb et al., 2001). The scarcity of measured data in African lakes is known despite long-term monitoring studies (Table 4). In contrast, studies in North America (Winter et al., 1995, 2003; Rosenberry et al., 2007) measured all parameters using a raft station. This is considered the best way to collect data for evaporation estimates (Lenters et al., 2005). 
Acknowledgements. This study was supported by grants from the Municipality of Sassari and the Sardinian Region, project PIT SS.1: Recovery of natural areas, the Lake Baratz, responsible Marge Cannas. The authors gratefully acknowledge Luisa Secci for providing help with water temperature survey data management during the first year of this project. We also thank Roberto Marrosu for his assistance in maintaining the raft structure and instrumentation. This paper benefited from reviews by W. James Shuttleworth and P. Le Moigne.

Edited by: J. Carrera

\section{References}

Adrian, R., O’Reilly, C. M., Zagarese, H., Baines, S. B., Hessen, D. O., Keller, W., Livingstone, D. M., Sommaruga, R., Straile, D., Van Donk, E., Weyhenmeyer, G. A., and Winder, G. A.: Lakes as sentinels of climate change, Limnol. Oceanogr., 54, 2283-2297, 2009.

Anderson, E. R.: Energy-budget studies, in: Water-Loss Investigation: Lake Hefner Studies, Prof. Pap., edited by: Tech. Rep., US Geol. Surv., USA, 269, 71-119, 1954.

Bouin, M.-N., Caniaux, G., Traullé, O., Legain, D., and Le Moigne, P.: Long-term heat exchanges over a Mediterranean lagoon, J. Geophys. Res., 117, D23104, doi:10.1029/2012JD017857, 2012.

Bowen, I. S.: The ratio of heat losses by conduction and by evaporation from any water surface, Phys. Rev., 27, 779-787, doi:10.1103/PhysRev.27.779, 1926.

Brutsaert, W.: Evaporation into the Atmosphere: Theory, History, and Applications, Kluwer Academic Publishers, Dordrecht, the Netherlands, 1982.

Buck, A. L.: New equations for computing vapor pressure and enhancement factor, J. Appl. Meteorol., 20, 1527-1532, 1981.

Crow, F. R. and Hottman, S. D.: Network density of temperature profile stations and its influence on the accuracy of lake evaporation calculations, Water Resour. Res., 9, 895-899, 1973.

dos Reis, R. J. and Dias, N. L.: Multi-season lake evaporation: energy-budget estimates and CRLE model assessment with limited meteorological observations, J. Hydrol., 208, 135-147, 1998.

Elsawwaf, M., Willems, P., Pagano, A., and Berlamont, J.: Evaporation estimates from Nasser Lake, Egypt, based on three floating station data and Bowen ratio energy budget, Theor. Appl. Climatol., 100, 439-465, 2010.

Gallego-Elvira, B., Baille, A., Martín-Górriz, B., and MartínezÁlvarez, V.: Energy balance and evaporation loss of an agricultural reservoir in a semi-arid climate (south-eastern Spain), Hydrol. Process., 24, 758-766, doi:10.1002/hyp.7520, 2010.

Gianniou, S. K. and Antonopoulos, V. Z.: Evaporation and energy budget in Lake Vegoritis, Greece, J. Hydrol., 345, 212-223, 2007.

Gorham, E.: Morphometric control of annual heat budgets in temperate lakes, Limnol. Oceanogr., 9, 525-529, 1964.

Gorham, E. and Boyce, F. M.: Influence of lake surface area and depth upon thermal stratification and the depth of the summer thermocline, J. Great Lakes Res., 15, 233-245, 1989.
Harbeck, G. E., Kohler, M. A., and Koberg, G. E.: Water-Loss Investigations: Lake Mead Studies, US Government Printing Office, Washington, D.C., 1958.

Hartmann, D. L.: Global Physical Climatology, Vol. 56, Academic Press, London, 1994.

Hoerling, M., Eischeid, J., Perlwitz, J., Quan, X., Zhang, T., and Pegion, P.: On the increased frequency of Mediterranean drought, J. Climate, 25, 2146-2161, doi:10.1175/JCLI-D-11-00296.1, 2012.

Krabbenhoft, D. P., Bowser, C. J., Anderson, M. P., and Valley, J. W.: Estimating groundwater exchange with lakes: 1. The stable isotope mass balance method, Water Resour. Res., 26, 2445-2453, 1990.

LaBaugh, J. W., Groschen, G. E., and Winter, T. C.: Limnological and Geochemical Survey of Williams Lake, Hubbard County, Minnesota, in: Series: Water-Resources Investigations, US Gov. Print. Off., Washington, DC, 81, 41, 1981.

Lee, T. M., Adams, D. B., Tihansky, A. B., and Swancar, A.: Methods, Instrumentation, and Preliminary Evaluation of Data for the Hydrologic Budget Assessment of Lake Lucerne, Polk County, Florida, US Geological Survey, US Department of the Interior, Denver, Colorado, 1991.

Lenters, J. D., Kratz, T. K., and Bowser, C. J.: Effects of climate variability on lake evaporation: results from a long-term Energy budget study of Sparkling Lake, northern Wisconsin (USA), J. Hydrol., 308, 168-195, doi:10.1016/j.jhydrol.2004.10.028, 2005.

Lewis Jr., W. M.: A revised classification of lakes based on mixing, Can. J. Fish Aquat. Sci., 40, 1779-1787, doi:10.1139/f83-207, 1983.

Myronidis, D., Stathis, D., Ioannou, K., and Fotakis, D.: An integration of statistics temporal methods to track the effect of drought in a shallow Mediterranean Lake, Water Resour. Manage., 26, 4587-4605, 2012.

Niedda, M. and Pirastru, M.: Hydrological processes of a closed catchment-lake system in a semi-arid Mediterranean environment, Hydrol. Process., 27, 3617-3626, doi:10.1002/hyp.9478, 2013.

Niedda, M., Pirastru, M., Castellini, M., and Giadrossich, F.: Simulating the hydrological response of a closed catchment-lake system to recent climate and land-use changes in semi-arid Mediterranean environment, J. Hydrol., 517, 732-745, 2014.

Nordbo, A., Launiainen, S., Mammarella, I., Leppäranta, M., Huotari, J., Ojala, A., and Vesala, T.: Long-term energy flux measurements and energy balance over a small boreal lake using eddy covariance technique, J. Geophys. Res., 116, D02119, doi:10.1029/2010JD014542, 2011.

O'Reilly, C. M., Alin, S. R., Plisnier, P. D., Cohen, A. S., and McKee, B. A.: Climate change decreases aquatic ecosystem productivity of Lake Tanganyika, Africa, Nature, 424, 766-768, 2003.

Parkhurst, R. S., Winter, T. C., Rosenberry, D. O., and Sturrock, A. M.: Evaporation from a small prairie wetland in the Cottonwood Lake area, North Dakota an energy-budget study, Wetlands, 18, 272-287, 1998.

Peel, M. C., Finlayson, B. L., and McMahon, T. A.: Updated world map of the Köppen-Geiger climate classification, Hydrol. Earth Syst. Sci., 11, 1633-1644, doi:10.5194/hess-11-16332007, 2007.

Penman, H. L.: Natural evaporation from open water, bare soil and grass, P. Roy. Soc. Lond. A, 193, 120-145, 1948. 
Pham, S. V., Leavitt, P. R., McGowan, S., and Peres-Neto, P.: Spatial variability of climate and land-use effects on lakes of the northern Great Plains, Limnol. Oceanogr., 53, 728-742, doi:10.4319/lo.2008.53.2.0728, 2008.

Priestley, C. H. B. and Taylor, R. J.: On the assessment of surface heat flux and evaporation using large-scale parameters, Mon. Weather Rev., 100, 81-92, 1972.

Robertson, E. and Barry, P. J.: The water and energy balances of Perch Lake (1969-1980), Atmos. Ocean, 23, 238-253, 1985.

Rosenberry, D. O., Winter, T. C., Buso, D. C., and Likens, G. E.: Comparison of 15 evaporation methods applied to a small mountain lake in the northeastern USA, J. Hydrol., 340, 149-166, 2007.

Sechi, N. and Luglié, A.: Phytoplankton in Sardinian reservoirs, Plant Biosyst., 130, 977-994, doi:10.1080/11263509609438380, 1996.

Shanahan, T. M., Overpeck, J. T., Sharp, W. E., Scholz, C. A., and Arko, J. A.: Simulating the response of a closedbasin lake to recent climate changes in tropical West Africa (Lake Bosumtwi, Ghana), Hydrol. Process., 21, 1678-1691, doi:10.1002/hyp.6359, 2007.

Shuttleworth, W. J.: Evaporation, in: Handbook of Hydrology, edited by: Maidment, D. R., McGraw-Hill, New York, USA, 4.14.53, 1993.

Sturrock, A. M., Winter, T. C., and Rosenberry, D. O.: Energy budget evaporation from Williams Lake: a closed lake in north central Minnesota, Water Resour. Res., 28, 1605-1617, 1992.
Vallet-Coulomb, C., Legessea, D., Gassea, F., Travic, Y., and Chernetd, T.: Lake evaporation estimates in tropical Africa (Lake Ziway, Ethiopia), J. Hydrol., 245, 1-18, 2001.

Wang, W., Xiao, W., Cao, C., Gao, Z., Hu, Z., Liu, S., and Lee, X.: Temporal and spatial variations in radiation and energy balance across a large freshwater lake in China, J. Hydrol., 511, 811-824, 2014.

Webb, E. K.: On estimating evaporation with fluctuating Bowen ratio, J. Geophys. Res., 65, 3415-3417, 1960.

Webb, E. K.: Further note on evaporation with fluctuating Bowen ratio, J. Geophys. Res., 69, 2649-2650, 1964.

Williamson, C. E., Saros, J. E., Vincent, W. F., and Smol, J. P.: Lakes and reservoirs as sentinels, integrators, and regulators of climate change, Limnol. Oceanogr., 54, 2273-2282, doi:10.4319/lo.2009.54.6_part_2.2273, 2009.

Winter, T. C. and Likens, G. E. (Eds.): Mirror Lake: Interactions Among Air, Land, and Water, Vol. 2, Univ. of California Press, Berkeley, 2009.

Winter, T. C., Rosenberry, D. O., and Sturrock, A. M.: Evaluation of 11 equations for determining evaporation for a small lake in the North Central United States, Water Resour. Res., 31, 983-993, 1995.

Winter, T. C., Buso, D. C., Rosenberry, D. O., Likens, G. E., Sturrock, A. M., and Mau, D. P.: Evaporation determined by the energy-budget method for Mirror Lake, New Hampshire, Limnol. Oceanogr., 48, 995-1009, 2003.

Yin, X. and Nicholson, S. E.: The water balance of Lake Victoria, Hydrolog. Sci. J., 43, 789-811, 1998. 